\title{
ФОРМУВАННЯ ДУХОВНО-ІНТЕЛЕКТУАЛЬНИХ УМІНЬ УЧНІВ НА УРОКАХ ХІМІЇ
}

\section{Хоу Ісюань}

здобувачка третього (освітньо-наукового) рівня вищої освіти кафедри освітології та інноваційної педагогіки, Харківський національний педагогічний університет імені Г. С. Сковороди, м. Харків, Україна

У статті зазначено, щьо хімія як природнича наук має великий потенціал для формування духовності й інтелектуальних умінь учнів. Розв 'язання задач і вправ вимагає сформованості вмінь аналізувати, узагальнювати, виявляти причинно-наслідкові зв'язки, робити висновки. Професіоналізм учителя дозволяє сформувати духовно-інтелектуальні вміння школярів на уроках хімії.

Ключові слова: хімія, учні, освітній прочес, учитель, прикладні задачі, інтегрування.

The article notes that chemistry as a natural science has great potential for the formation of spirituality and intellectual skills of students. Solving problems and exercises requires the formation of skills to analyze, generalize, identify cause-and-effect relationships, draw conclusions. The professionalism of the teacher allows to form the spiritual and intellectual skills of students in chemistry lessons.

Key words: chemistry, students, educational process, teacher, applied tasks, integration.

Хімія як одна 3 природничих наук водночас є складною та цікавою. Складність полягає в тому, що розв’язувати задачі й вправи можуть не всі учні. Учням бракує логічності мислення, кретивності й творчих здібностей, конструктивних умінь, нерідко вони не задумуються над практичним значенням хімічних речовин. Як наголошує Я. Кузьмич, «вивчення хімії в школі сприяє формуванню світогляду учнів і цілісної картини світу, розуміння необхідності хімічної освіченості для вирішення повсякденних життєвих проблем, вихованню належної поведінки в навколишньому середовищі» [2, с. 2]. Як свідчить аналіз власного педагогічного досвіду, школярам цікаво на уроках хімії в тому випадку, коли вони експериментують, відшукують причинно-логічні зв'язки, працюють з моделями і таблицею хімічних елементів Д. Менделєєва.

Метою статті — виявлення причинно-наслідкових зв’язків між хімією як природничою наукою та духовно-інтелектуальним розвитком учнів. 
Розділ І. Ціннісні орієнтири духовно-інтелектуального виховання, розвиток духовно-інтелектуальних якостей особистості в умовах співпраці й інклюзії

Формування духовно-інтелектуальних умінь учнів на уроках хімії відбувається в процесі розв’язання задач. Як зазначає С. Ярошенко [4], інтегровані прикладні задачі та вправи спрямовані на розвиток інтелектуальних умінь, формування наукового стилю мислення, підвищення інтересу до пізнання нового і невідомого раніше, розширення кругозору й обізнаності в різних питаннях. Прикладний характер таких задач і вправ дозволяє учням не лише знати про хімічний склад ліків, матеріалів будівництва, фарбів для написання живопису, але й думати про користь та шкідливість цих речовин, обережне поводження 3 хімічними реактивами.

Останнім часом учителі хімії відшукують нові шляхи формування компетентності в галузі природничих наук, техніки і технологій, застосовують нетрадиційні методи і форми навчання школярів, інформаційно-комунікаційні технології. Безумовно, новітні підходи до організації освітнього процесу в закладах загальної середньої освіти підвищують рівень сформованості пізнавального інтересу, розвивають критичне мислення та уміння мобільно застосовувати знання в нових ситуаціях. Так, уявна подорож таблицею хімічних елементів Д. Менделєєва занурює школярів у світ валентностей та електронних конфігурацій хімічних сполучень. Такі мандрівки збагачують уяву школярів про побудову, властивості, значення й місце хімічних елементів у природі, житті й побуті людини.

Китайські дослідники [1; 3] приділяють особливу увагу самореалізації вчителя, в тому числі вчителя хімії. Учителі мають виконувати навчальну програму, проєктувати нові ідеї, активізувати школярів до творчості, активності, ініціативності. Нам імпонує думка про те, що вчителеві необхідно розуміти значущість своєї професії, зберігати ентузіазм у педагогічній діяльності, будувати кар'єру й досягати нових вершин професіоналізму, не забувати про емоційну стійкість у роботі з учнями та батьками.

Цінним у дослідженнях є думки про самореалізацію вчителя, іiі прикладні аспекти. Учителі мають поважати своїх учнів, ураховувати їхні навчальні можливості, реалізовувати принцип доступності в навчанні. Необхідно довіряти й організовувати співпрацю із школярами та їхніми батьками. Самоосвітня діяльність $є$ важливою складовою самореалізації вчителя, розвитку його духовно-інтелектуального світу. Цілком погоджуємося в тому, що нині ми мало читаємо журналів у га- 
лузі хімії, недостатньо стимулюємо школярів до читання книг, збірок, журналів, у яких популярно розповідається про хімічні речовини та їх роль у житті людині. Наприклад, на телебаченні цікавою є «Корисна програма», на якій йдеться про правильне харчування й вибір екологічно чистих продуктів. Наводяться приклади зловживання хімічними сполуками в процесі приготування продуктів споживання.

Отже, хімія як природнича наук має великий потенціал для формування духовності й інтелектуальних умінь учнів. Розв’ язання задач і вправ вимагає сформованості вмінь аналізувати, узагальнювати, виявляти причинно-наслідкові зв'язки. Професіоналізм вчителя дозволяє сформувати духовно-інтелектуальні вміння школярів на уроках хімії.

\section{Список використаних джерел:}

1. 王建忠. 浅议教师如何自我发展[J]. 课程教育研究,2014(26):215.

Ван Цзяньчжун. Обсуждение вопроса о самореализации учителей. Изучение учебных программ. № 26. 2014. С.215.

2. Кузьмич Я. В. Роль інтерактивного навчання на уроках хімії в системі професійно-технічної освіти. Молодий учений. №12 (64). 2018. С. 1 - 4.

3. 钱兵, 孙在丽. 教师自我发展意识的迷失与唤醒[J]. 当代教育科学, 2018(08):44-46. Цянь Бин, Сунь Заили. Активизация сознания самореализации учителя. Современная образовательная наука. № 08. 2018. С. 44 - 46.

4. Ярошенко С. В. Використання інтегрованих задач і вправ прикладного характеру на уроках хімії. Режим доступу: https://vseosvita.ua/library/ navcalno-metodicnij-posibnik-vikoristanna-integrovanih-zadac-i-vpravprikladnogo-harakteru-na-urokah-himii-251846.html (Дата звернення: 18.10.2021). 